\title{
Low UV-B radiation and substrate acidity impact on photosynthetic parameters of Brassica napus
}

\author{
Irena Januškaitienė ${ }^{\star}$ \\ Vytautas Magnus University, \\ Vileikos 8 , \\ LT-44404 Kaunas, \\ Lithuania
}

The aim of this study was to assess combined effect of $1 \mathrm{kJm}^{-2} \mathrm{~d}^{-1}$ UV-B radiation and substrate acidity $(\mathrm{pH} 4.8)$ on photosynthesis and growth of summer rape (Brassica napus) in a controlled environment. Rape were sown in a neutral $(\mathrm{pH}$ 6.0-6.5) peat substrate, when 2 nd true leaf unfolded, growth substrate was acidified using $0.07 \mathrm{mM} \mathrm{H}_{2} \mathrm{SO}_{4}$ concentration solution and UV-B radiation exposure was started. Duration of the experiment: five days. Gas exchange parameters were measured with portable photosynthesis system LI-6400. Content of chlorophyll was evaluated spectrophotometrically. The results showed that the highest inhibition on Brassica napus growth and photosynthetic parameters was under combined effect of $1 \mathrm{kJm}^{-2} \mathrm{~d}^{-1} \mathrm{UV}-\mathrm{B}$ radiation and $\mathrm{pH} 4.8$ substrate acidity. The impact of single $1 \mathrm{kJm}^{-2} \mathrm{~d}^{-1} \mathrm{UV}-\mathrm{B}$ radiation on investigated parameters was low and statistically insignificant, except transpiration rate and water use efficiency. Single substrate acidity affected in 58.6\% $(p<0.05)$ decrease in photosynthetic rate, almost twofold decrease of transpiration rate, and 3.8\% ( $\mathrm{p}<0.05)$ decrease in intercellular $\mathrm{CO}_{2}$ concentration, and $27.1 \%(\mathrm{p}<0.05)$ increase in water use efficiency, compared to the reference treatment. Combined substrate acidity and UV-B radiation effect on photosynthetic rate was the highest, when the decrease was $80.6 \%$ ( $p<0.05)$, compared to the reference treatment. The changes of transpiration rate under combined effect of investigated stressors compared to the reference treatment were insignificant $(p>0.05)$. The increase (by $2 \%, p<0.05)$ of intercellular $\mathrm{CO}_{2}$ concentration of Brassica napus affected by combined impact of investigated stressors shows that higher negative impact was on enzymatic reactions of photosynthesis than on transpiration. The highest negative effect on content of photosynthetic pigments and biomass accumulation also was of combined effect of investigated stressors.

Key words: net photosynthesis, intercellular $\mathrm{CO}_{2}$ concentration, transpiration, water use efficiency, photosynthetic pigments, dry biomass, Brassica napus

* Corresponding author. E-mail: I.Januskaitiene@gmf.vdu.lt 


\section{INTRODUCTION}

Abiotic and biotic stresses cause alterations in normal physiological processes of all plant organisms. Recently, along natural stress factors plant organisms are imposed to a large scale of new stressors related to human activity. All these stresses decrease the biosynthetic capacity of plant organisms, alter their normal functions and cause damages which may lead to plant death $[1,2]$.

During the later part of the 20th century the average of UV-B irradiances in the biosphere has increased. Ultraviolet wavelengths greater than $280 \mathrm{~nm}$ (UV-B radiation) are an ubiquitous component of the solar radiation, but their levels considerably vary in the biosphere spatially and temporally [3]. UV-B causes damage to DNA, proteins and membranes, impedes photosynthetic activities, and disturbes plant growth [4]. Other studies demonstrate that increased levels of UV-B mainly affect PS II in the thylakoid membranes, specifically the functionality of the D1 protein, decreasing the electron transport efficiency [5]. UV-B has been also shown to affect the activity of enzymes of the carbon reduction metabolism, mainly Rubisco, and in this way directly involved in the $\mathrm{CO}_{2}$ assimilation and biomass production [6]. UV-B radiation decreases plant height, stem length and leaf area in a number of species including wheat, rice, pea, sunflower, tomato and lettuce [7]. Since UV-B induces general stress responses in plants, the syntheses of a broad variety of metabolites regarding growth, development and defence may be affected [8]. Plant tissues respond to UV-B by inducing cellular protective processes that include changes in phenylpropanoid metabolism with increased synthesis of UV-B absorbing compounds, mostly flavonoids and other related phenolics [9]. Although UVabsorbing compounds primarily protect the DNA molecule [3]. Also, the effects of UV-B radiation on photosynthesis vary among species. In some species, UV-B radiation can negatively affect leaf photosynthesis $[10,11]$, but in some others it has little or no effect [12].
The problem of soil acidification resulting from the acid rains and application of fertilizers has been known for many years. The acidification can result in negative impact on root metabolism and decrease plant growth and yields when soil $\mathrm{pH}$ falls to less than critical thresholds (usually less than 5.5) which leads to increased activity of aluminum (Al) and manganese $(\mathrm{Mn})[13,14]$. Increased concentration of aluminium ions $\left(\mathrm{Al}^{3+}\right)$ in soil inhibits root elongation by disrupting the function of the plasma membrane, cell wall, Ca homeostasis and signal transduction pathways [15]. This reduces the capacity of roots to explore soil for moisture and nutrients [16]. Soil acidification can also lead to leaf yellowing and whole plant net photosynthetic rate decrease [17], because of all the mentioned negative impacts on root $[15,16]$ and reduced content of chlorophylls [17].

Several studies have demonstrated that other environmental factors can influence the effect of UV-B on plants, which may explain the inconclusive results of many field studies. For example, water supply has been shown to influence the effect of supplemental (1.2 $\mathrm{kJm}^{-2} \mathrm{~d}^{-1} \mathrm{UV}$ above ambient) UV-B on the growth and photosynthetic electron flow of several Arctic bryophytes [18]. Paoletti [19] has studied UV-B and acid rain effects on beech (Fagus sylvatica L.) and holm oak (Quercus ilex L.) leaves. Beech leaves were more sensitive to UV-B radiation and to acid fog spraying than those of holm oak. The combined treatment of UV-B radiation and acid fog induced the highest level of necrosis in leaf tissues, but of the two factors it was the acid fog that caused the most severe damage [19]. While our earlier experiments with radish showed a slightly different plant response to combined effect of the mentioned stressors, i. e. the decrease of photosynthesis of radish plants treated with substrate acidity and UV-B radiation was lower compared to the single impact of the substrate acidity. And UV-B radiation stimulated both enzymatic reactions of photosynthesis and water use efficiency of radish plants grown in acidified peat substrates [20]. So this 
study focused on the combined impact of low UV-B radiation and substrate acidity on photosynthesis and growth of summer rape (Brassica napus) plants.

\section{MATERIALS AND METHODS}

Summer rape (Brassica napus; cv. 'Landmark') was chosen for investigation. Experiments were carried out in a vegetation room with controlled environment: photoperiod $-14 \mathrm{~h}$, average temperature of $20-25{ }^{\circ} \mathrm{C}$, relative humidity - 60\%. "Philips Master Green Power CG T" $600 \mathrm{~W}$ lamps, light intensity at the level of plants $14000 \mathrm{Lx}$, provided light.

Rape (10 per pot) were sown in a neutral (pH 6.0-6.5) peat substrate in $5 \mathrm{~L}$ pots $(21 \mathrm{~cm}$ in diameter). In each treatment there were three pots of replication. When 2 nd true leaf unfolded, i. e. at leaf development stage (BBCH-12) [21] rape plants were divided into four groups: I) reference treatment group (substrate $\mathrm{pH}$ 6.5) was watered with distillated water all the time; II) rape plants were exposed to $1 \mathrm{kJm}^{-2} \mathrm{~d}^{-1}$ UV-B radiation; III) growth substrate of rape plants was watered with $0.07 \mathrm{M}$ concentration $\mathrm{H}_{2} \mathrm{SO}_{4}$ solution and growth substrate acidified till $\mathrm{pH}$ 4.8; IV) plants growth substrate was acidified as mentioned above till $\mathrm{pH} 4.8$ and rape plants exposed to $1 \mathrm{kJm}^{-2} \mathrm{~d}^{-1} \mathrm{UV}-\mathrm{B}$ radiation. The treatment variants were chosen according to earlier experiments at the Environmental Department of the VMU [20]. Duration of the experiment was five days.

Investigated indices net photosynthetic rate, intercellular $\mathrm{CO}_{2}$ concentration, transpiration, water use efficiency, photosynthetic pigments and leaf area, fresh and dry biomass of shoot (foliage) of rape were measured at the end of the experiment.

Gas exchange parameters were measured with portable photosynthesis system LI-6400 (LI-COR, USA). Net photosynthetic rate (Pn) $\left(\mu \mathrm{mol} \mathrm{CO} \mathrm{m}^{-2} \mathrm{~s}^{-1}\right)$, intercellular $\mathrm{CO}_{2}$ concentration $(\mathrm{Ci})\left(\mu \mathrm{mol} \mathrm{CO} \mathrm{mol} \mathrm{air}^{-1}\right)$, transpiration (Tn) $\left(\mathrm{mmol} \mathrm{H}_{2} \mathrm{O} \mathrm{m}^{-2} \mathrm{~s}^{-1}\right)$ and water use efficiency (WUE) $\left(\mu \mathrm{mol} \mathrm{CO}_{2} \mathrm{mmol} \mathrm{H}_{2} \mathrm{O}^{-1}\right)$ of second fully expanded leaves were registered every 3 seconds for 10 minutes; from these data were calculated a mean of day of measured indices. Environment conditions during experiments were as follows: air flow rate $-400 \mu \mathrm{mol} \mathrm{s}^{-1}$; block and leaf temperature $-23{ }^{\circ} \mathrm{C} ; \mathrm{CO}_{2}$ concentration in sample cell - 380-400 $\mu \mathrm{mol} \mathrm{CO}_{2} \mathrm{~mol}^{-1}$; relative humidity in sample cell - $30 \%$; lightness in quant $-110 \mu \mathrm{mol} \mathrm{m} \mathrm{m}^{-2} \mathrm{~s}^{-1}$.

The second fully expanded leaves were harvested and photosynthetic pigments were analysed using a spectrophotometer (Genesys 6, ThermoSpectronic, USA) in $100 \%$ acetone extracts prepared according to Wettstein's method [21]. Photosynthetic pigments were expressed in $\mathrm{mg} \mathrm{g}^{-1}$ of fresh weight.

The leaf area was determined using millimeter graph paper method. The leaves of five randomly taken plants from each variant were cut and spread over millimeter graph paper, and the area of the leaf was counted. The leaf area was expressed in $\mathrm{cm}^{2}$ plant ${ }^{-1}$.

At the end of the experiment the plants were harvested and dried in an oven at $60{ }^{\circ} \mathrm{C}$ until constant dry foliage biomass was obtained. The biomasses were expressed in $\mathrm{mg} \mathrm{plant}^{-1}$.

ANOVA was used to determine the effects of substrate acidity and UV-B. For the comparison of independent variables Student's $t$ and U tests were used. All analyses were performed by STATISTICA and the results were expressed as mean values and their confidence intervals (CI) $(\mathrm{p}<0.05)$.

\section{RESULTS}

Single $1 \mathrm{kJm}^{-2} \mathrm{~d}^{-1}$ UV-B radiation had no statistically significant effect on net photosynthesis of rape plants, while substrate acidity decreased it markedly (Fig. 1). On the last day of the experiment the substrate acidity ( $\mathrm{pH}$ 4.8) decreased the net photosynthesis of Brassica napus by $58.6 \%(\mathrm{p}<0.05)$ compared to the reference treatment (substrate $\mathrm{pH} 6.5$ ). The inhibition of net photosynthesis of rape plants treated with both investigated factors (UV-B and substrate acidity) were the highest compared to the single impacts of the substrate 
acidity and UV-B radiation, when $4.8 \mathrm{pH}$ substrate and $1 \mathrm{kJm}^{-2} \mathrm{~d}^{-1}$ UV-B radiation dose decreased the net photosynthesis by $80.6 \%$, compared to the reference treatment (pH 6.5). Compared to the combined impact of the investigated factors on photosynthesis of rape with single impact of UV-B radiation the net photosynthesis decreased by $76.4 \%(\mathrm{p}<0.05)$ and with $\mathrm{pH} 4.8$ substrate - by $21.9 \%(\mathrm{p}<0.05)$.

Single $1 \mathrm{kJm}^{-2} \mathrm{~d}^{-1} \mathrm{UV}-\mathrm{B}$ radiation had no statistically significant effect on intercellular $\mathrm{CO}_{2}$ concentration of Brassica napus (Fig. 2). Intercellular $\mathrm{CO}_{2}$ concentration of rape leaves grown in $\mathrm{pH} 4.8$ acidified substrate decreased by $3.8 \%(\mathrm{p}<0.05)$, but it increased by $1.6 \%(\mathrm{p}<0.05)$ under the combined impact of $\mathrm{pH} 4.8$ and UV-B radiation (Fig. 2).

The changes of transpiration rate under investigated factors varied a slightly different tendency as net photosynthesis (Fig. 1), i. e. single $1 \mathrm{kJm}^{-2} \mathrm{~d}^{-1}$ UV-B radiation caused statistically significant increase in Tn of rape plants, while single substrate acidity decreased it 2.2 times (Fig. 3). The combined substrate $\mathrm{pH} 4.8$ and $1 \mathrm{kJm}^{-2} \mathrm{~d}^{-1} \mathrm{UV}-\mathrm{B}$ radiation dose impact decreased the Tn only by $4.5 \%(p>0.05)$ compared to the reference treatment (pH 6.5).

Both investigated factors affected water use efficiency of rape too (Fig. 4). Single $1 \mathrm{kJm}^{-2} \mathrm{~d}^{-1} \mathrm{UV}-\mathrm{B}$ radiation decreased WUE by $24.9 \%$ ( $\mathrm{p}<0.05)$ of rape plants, while single substrate acidity increased it by $27.1 \%(\mathrm{p}<0.05)$ (Fig. 4$)$. The combined substrate $\mathrm{pH} 4.8$ and $1 \mathrm{kJm}^{-2} \mathrm{~d}^{-1}$ UV-B radiation impact affected the decrease of WUE by $72.6 \%(\mathrm{p}<0.05)$ compared to the reference treatment ( $\mathrm{pH}$ 6.5).

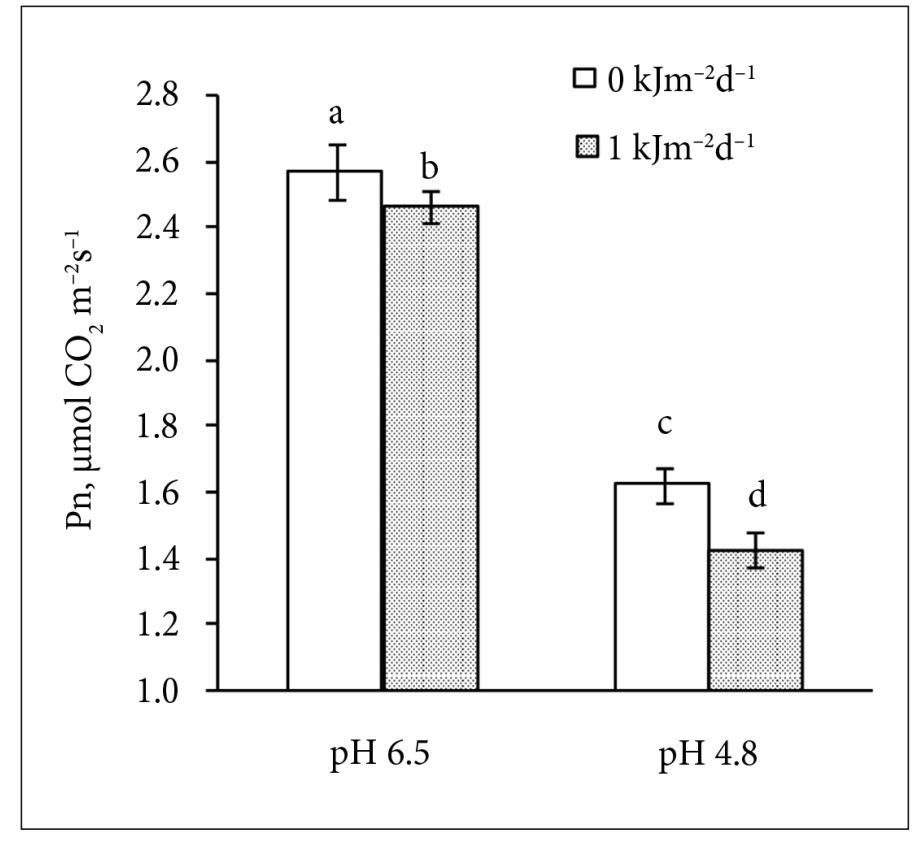

Fig. 1. The effects of $1 \mathrm{kJm}^{-2} \mathrm{~d}^{-1} \mathrm{UV}-\mathrm{B}$ radiation and different (pH 6.5 - reference treatment, $\mathrm{pH} 4.8$ ) substrate acidity on net photosynthetic rate $(\mathrm{Pn})$ of Brassica napus. The values are means $\pm \mathrm{CI}_{0.05}$. Significant differences $(\mathrm{p}<0.05)$ between treatments are denoted with different letters

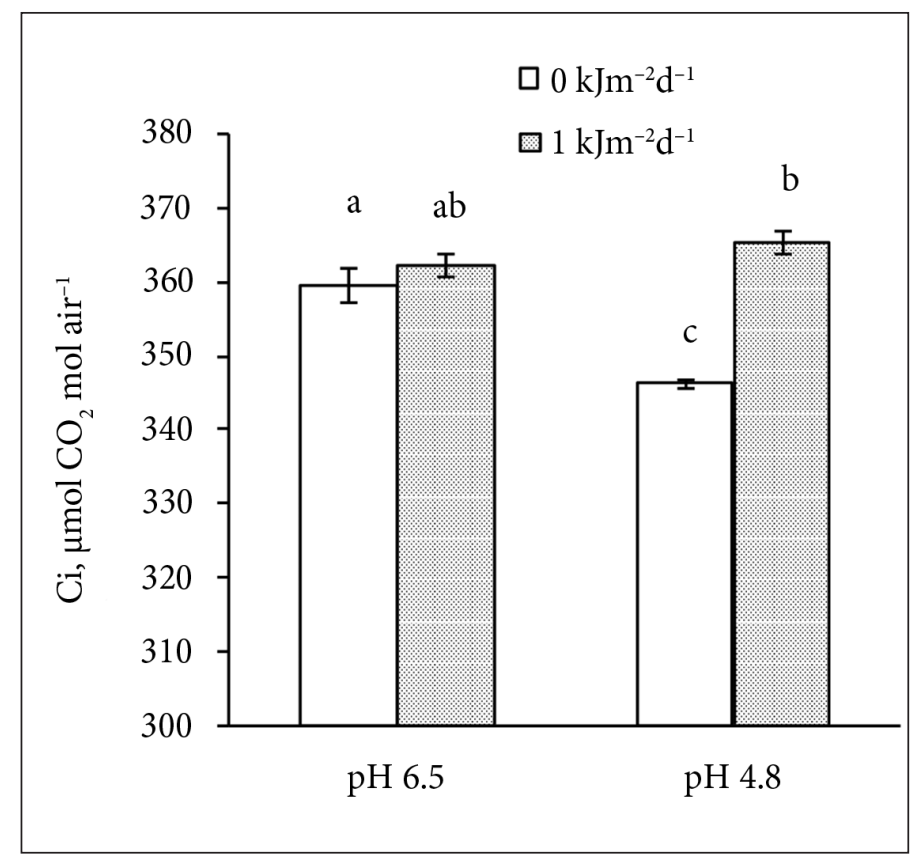

Fig. 2. The effects of $1 \mathrm{kJm}^{-2} \mathrm{~d}^{-1} \mathrm{UV}-\mathrm{B}$ radiation and different ( $\mathrm{pH} 6.5$ - reference treatment, $\mathrm{pH} 4.8$ ) substrate acidity on intercellular $\mathrm{CO}_{2}$ concentration (Ci) of Brassica napus. The values are means $\pm \mathrm{CI}_{0.05}$. Significant differences $(\mathrm{p}<0.05)$ between treatments are denoted with different letters 


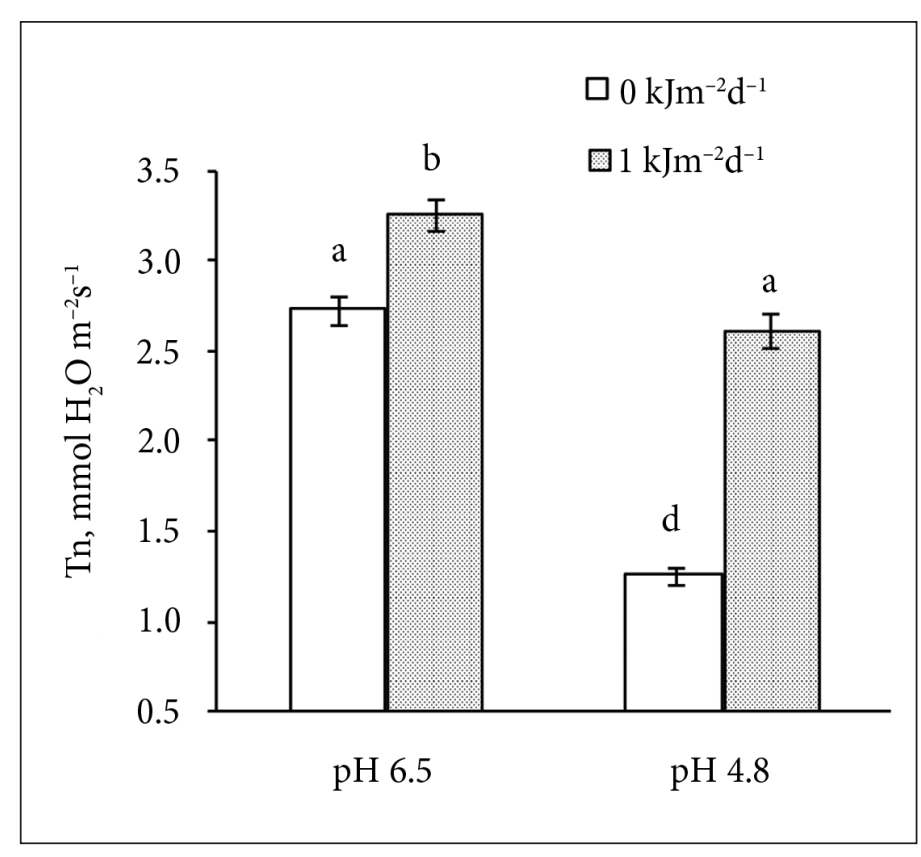

Fig. 3. The effects of $1 \mathrm{kJm}^{-2} \mathrm{~d}^{-1} \mathrm{UV}-\mathrm{B}$ radiation and different ( $\mathrm{pH} 6.5$ - reference treatment, $\mathrm{pH} 4.8$ ) substrate acidity on transpiration rate (Tn) of Brassica napus. The values are means $\pm \mathrm{CI}_{0.05}$. Significant differences $(\mathrm{p}<0.05)$ between treatments are denoted with different letters

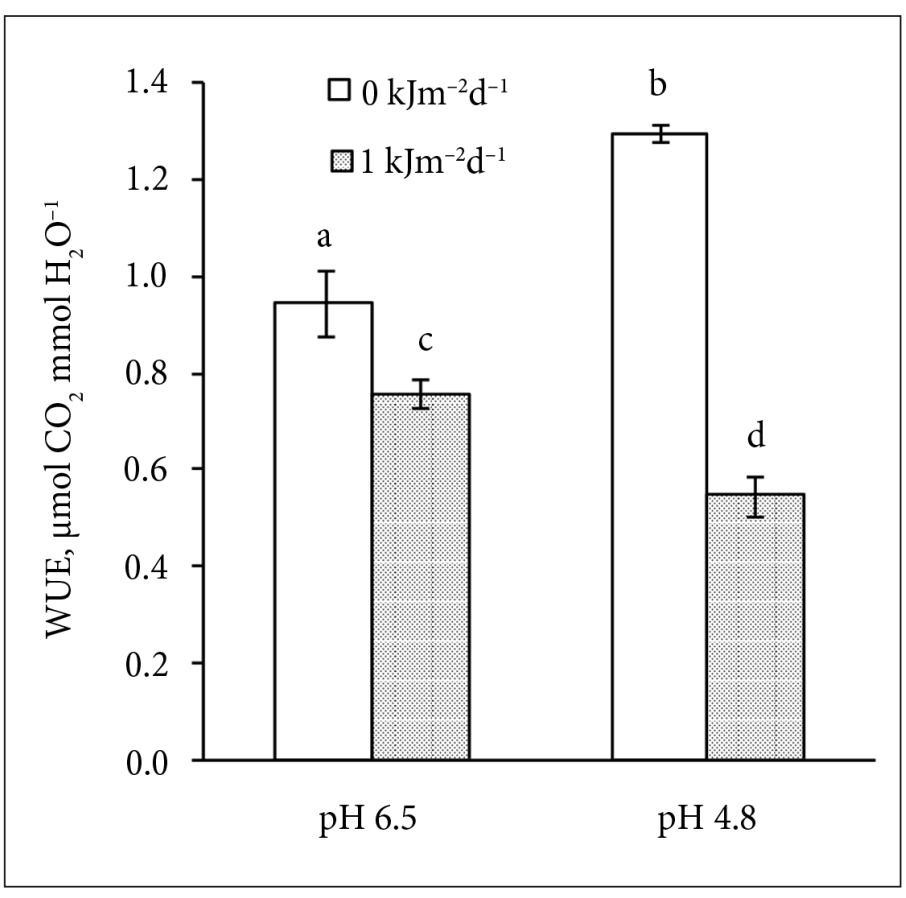

Fig. 4. The effects of $1 \mathrm{kJm}^{-2} \mathrm{~d}^{-1} \mathrm{UV}-\mathrm{B}$ radiation and different ( $\mathrm{pH} 6.5$ - reference treatment, $\mathrm{pH} 4.8$ ) substrate acidity on water use efficiency (WUE) of Brassica napus. The values are means $\pm \mathrm{CI}_{0.05}$. Significant differences $(\mathrm{p}<0.05)$ between treatments are denoted with different letters
Single $1 \mathrm{kJm}^{-2} \mathrm{~d}^{-1}$ UV-B dose impact decreased chlorophyll $a$ and chlorophyll $b$ content by $23.2 \%$ ( $p>0.05$ ) and $26.5 \%$ ( $\mathrm{p}>0.05$ ) respectively, compared to the reference treatment (Fig. 5). While the single $\mathrm{pH} 4.8$ substrate acidity effected in chlorophyll $a$ and $b$ content increase by $25.0 \%$ and $15.4 \%$ respectively, but also statistically insignificant compared to the reference treatment ( $\mathrm{pH}$ 6.5). Chlorophyll $b$ was more sensitive to combined UV-B radiation and substrate acidity impact than chlorophyll $a$ and carotenoids. Thus the combined UV-B and substrate acidity effect caused 91.7\% ( $\mathrm{p}<0.05), 2.1$ times $(\mathrm{p}<0.05)$ and $82.6 \%(\mathrm{p}<0.05)$ decreases of chlorophyll $a$, chlorophyll $b$ and carotenoids respectively, compared to the reference treatment.

Combined impact of UV-B radiation and substrate acidity on biomass accumulation followed the same tendency as on other investigated indices, i. e. the decreases were higher compared to the single impact of the investigated factors. Leaf area, fresh and dry foliage biomasses of Brassica napus plants exposed to single UV-B radiation increased by $11.3,14.3$ and $22.6 \%$ respectively, but statistically insignificant (Fig. 6a, b, c). Single and combined substrate acidity effect decreased leaf area by $77.6 \%$ $(\mathrm{p}<0.05)$ and $73.2 \%(\mathrm{p}<0.05)$ respectively, compared to the reference treatment. Only combined impact of substrate acidity ( $\mathrm{pH}$ 4.8) led to statistically significant decrease of dry biomass of foliage, when it decreased by $70.6 \%$, compared to the reference treatment $(\mathrm{pH}$ 6.5) $(\mathrm{p}<0.05)$. 


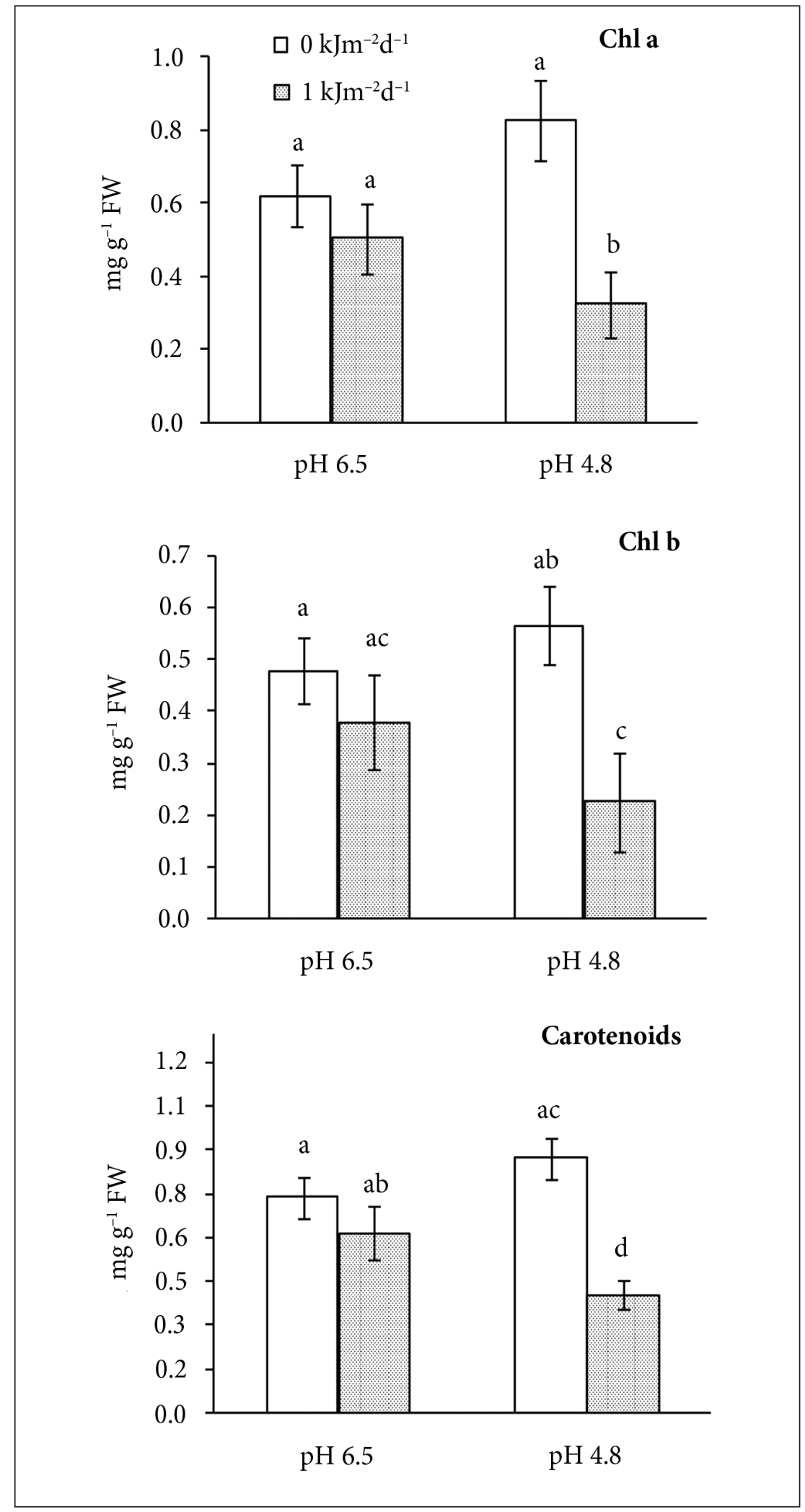

Fig. 5. The effects of $1 \mathrm{kJm}^{-2} \mathrm{~d}^{-1} \mathrm{UV}$-B radiation and different $(\mathrm{pH} 6.5$ - reference treatment, $\mathrm{pH} 4.8$ ) substrate acidity on content of chlorophyll $a(\mathrm{Chl} \mathrm{a})$, chlorophyll $b(\mathrm{Chl} \mathrm{b})$ and carotenoids in Brassica napus leaves. FW - fresh weight. The values are means $\pm \mathrm{CI}_{0.05}$. Significant differences $(\mathrm{p}<0.05)$ between treatments are denoted with different letters 


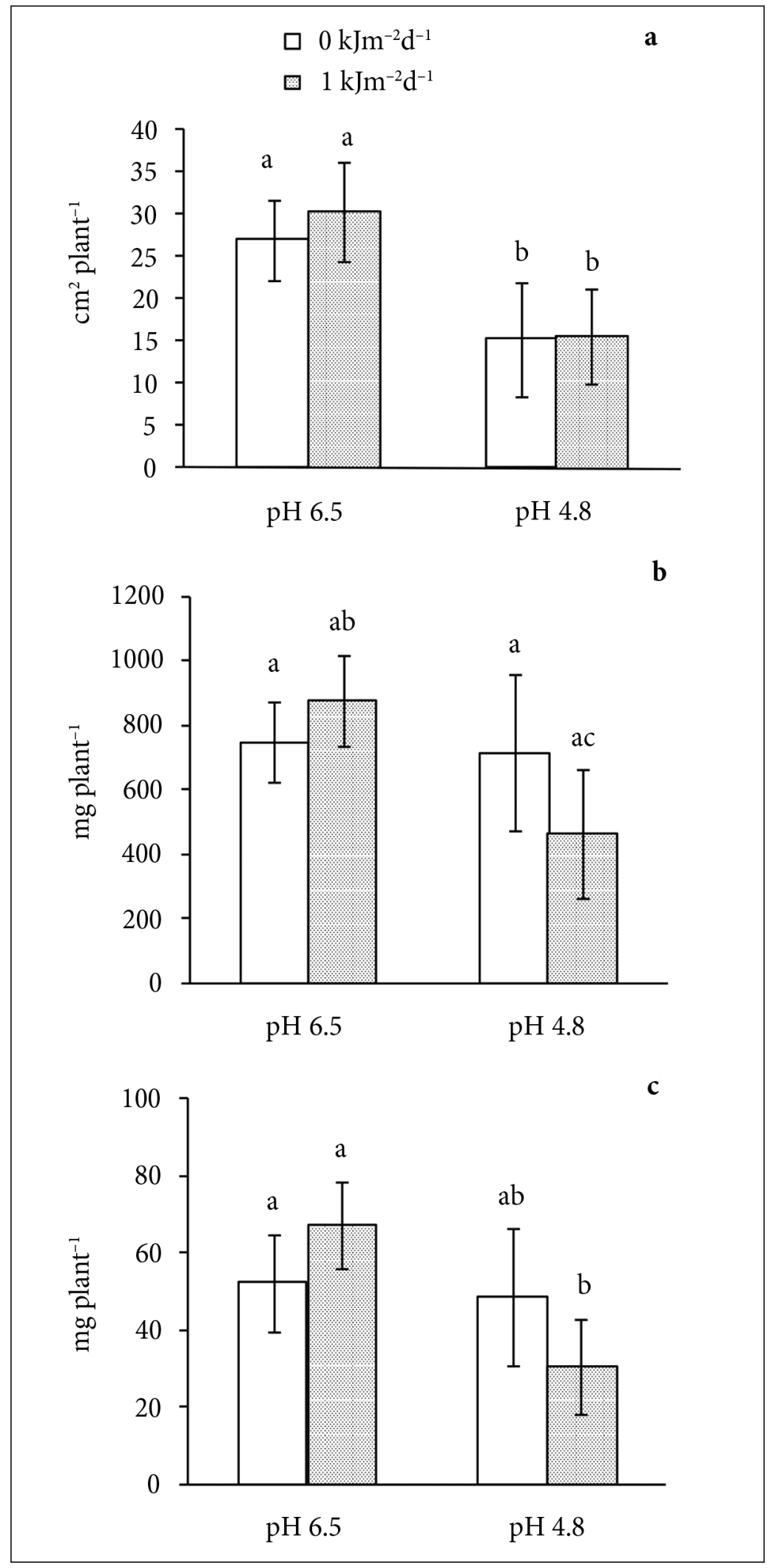

Fig. 6. The effects of $1 \mathrm{kJm}^{-2} \mathrm{~d}^{-1} \mathrm{UV}-\mathrm{B}$ radiation and different ( $\mathrm{pH} 6.5$ - reference treatment, $\mathrm{pH}$ 4.8) substrate acidity on leaf area (a), content of fresh (b) and dry (c) shoot biomasses of Brassica napus plants. The values are means $\pm \mathrm{CI}_{0.05}$. Significant differences $(\mathrm{p}<0.05)$ between treatments are denoted with different letters 


\section{DISCUSSION}

The combined influence of different stress factors can lead to death of a plant or can increase its resistance to subsequent unfavourable impacts. The effects vary among species [22]. Some plants respond positively to the ambient levels of UV-B radiation, but the majority react negatively. Enhanced levels of UV-B radiation can commonly negatively affect plant physiological processes and growth [24]. Decrease in plant growth is considered to result from damage of DNA [25] to photosynthetic apparatus [12]. In our research, the investigated $1 \mathrm{kJm}^{-2} \mathrm{~d}^{-1} \mathrm{UV}-\mathrm{B}$ radiation caused photosynthetic rate decrease (Fig. 1), but stimulated transpiration rate (Fig. 3); compared to non-exposed Brassica napus plants. Qaderi and Reid [26] got similar results, when low $4.2 \mathrm{UV}-\mathrm{B} \mathrm{kJm}^{-2} \mathrm{~d}^{-1}$ radiation affected decrease of photosynthetic rate and water use efficiency and increase of transpiration rate for Brassica napus plants [26]. Single substrate acidity resulted in a high $(58.6 \%, p<0.05)$ photosynthetic rate inhibition and in the highest (2.2 times, $p<0.05)$ decrease of transpiration rate, compared to the reference treatment (Figs. 1 and 3). This shows that stomata were closed, WUE increased (Fig. 4), and this resulted in $27.1 \%$ $(p<0.05)$ decrease of $\mathrm{Ci}$ (Fig. 2) as $\mathrm{CO}_{2}$ did not reach the intercellular area. In the study of Izuta et al. [27], photosynthetic rate was also significantly reduced in the seedlings grown in the acidified soils. The highest inhibition of net photosynthesis and the highest intercellular $\mathrm{CO}_{2}$ concentration of Brassica napus plants grown in $\mathrm{pH} 4.8$ acidified peat substrate and exposed to UV-B shows that stress had intense effect on reactions of dark phase of photosynthesis. The net rate of $\mathrm{CO}_{2}$ assimilation is determined by biophysical processes, which include $\mathrm{CO}_{2}$ transport through the leaf and stomata, and biochemical processes located in the cells of plants. In this research, under combined impact of investigated factors stomata were not closed, because transpiration rate changed statistically insignificantly (Fig. 3), hence $\mathrm{CO}_{2}$ transport into leaf was normal. Soil acidification inhibits biosynthesis of Rubisco in leaves [27], and the increase in intercellular $\mathrm{CO}_{2}$ level indicates that net photosynthesis is reduced by reducing $\mathrm{CO}_{2}$ fixation by Rubisco, or can also include conditions in which enzymes of the Calvin cycle were affected negatively [28].

Single UV-B radiation affected the nonsignificant decrease of content of chlorophyll $a$, chlorophyll $b$ and carotenoids compared to the reference treatment (Fig. 5). In some studies UV-B radiation increases chlorophyll content [29], in others - decreases [12, 30], or has no affect [31]. UV-B radiation may be attenuated in leaves by leaf cuticles, or by UVabsorbing compounds produced and deposited in leaf epidermal cells or hairs [32] or by antioxidant systems $[33,4]$. The single $\mathrm{pH} 4.8$ substrate acidity affected also in statistically insignificant increase of chlorophyll $a$ and $b$ content compared to the reference treatment (Fig. 5). In most studies with increasing soil acidity, chlorophyll contents linearly decreases [34], but there are also different results reported earlier by Shan et al. [35] when chlorophyll contents of the seedlings linearly increased with increasing acidity of stimulated acid rain; while the combined UV-B and substrate acidity effect caused very high decreases of chlorophyll $a$, chlorophyll $b$ and carotenoids. UV-B radiation can negatively affect plant physiological processes [24] because of the damage of DNA [25] and photosynthetic apparatus [12] as also shown in Figs. 1, 2, 4 and 5 of this research. Additional impact of substrate acidity increased this negative effect.

The acidification can result in negative impacts on root metabolism and decrease plant growth and yields when soil $\mathrm{pH}$ falls to less than critical thresholds $(<5.5 \mathrm{pH})[13,14]$. The combined treatment of UV-B radiation and acid fog affected the highest level of decreases in the research of Paoletti et al. [19]. The results of this research showed the same tendency, however, a significant impact on biomass accumulation was not determined except in case of Brassica napus affected by both (substrate acidity and 
UV-B radiation) factors (Fig. 6). Under single and combined UV-B radiation impacts the increase of the leaf area of rape was detected, but not statistically significant (Fig. 6). Minimal effects of low UV-B radiation on biomass accumulation of other plants were assessed too $[36,18]$.

\section{CONCLUSIONS}

Single $1 \mathrm{kJm}^{-2} \mathrm{~d}^{-1}$ UV-B radiation impact on most investigated parameters was low and statistically insignificant, except transpiration rate and water use efficiency. UV-B radiation increased transpiration rate by $16.4 \%$ and decreased water use efficiency by $24.9 \%$ of rape plants statistically significant compared to the reference treatment.

Single substrate acidity affected in 58.6\% $(\mathrm{p}<0.05)$ decrease in photosynthetic rate, almost twofold decrease of transpiration rate, and $3.8 \%(\mathrm{p}<0.05)$ decrease in intercellular $\mathrm{CO}_{2}$ concentration, and 27.1\% ( $\left.\mathrm{p}<0.05\right)$ increase in water use efficiency compared to the reference treatment.

Combined UV-B radiation and substrate acidity impact affected the highest $80.6 \%$ $(\mathrm{p}<0.05)$ decrease of photosynthetic rate compared to the reference treatment. The increase (by $2 \%, \mathrm{p}<0.05$ ) of intercellular $\mathrm{CO}_{2}$ concentration of Brassica napus affected by both investigated stressors shows that higher negative impact was on enzymatic reactions of photosynthesis than on transpiration (Tn changed statistically insignificantly compared to the reference treatment).

Also, the highest negative effect on content of photosynthetic pigments and biomass accumulation was of the combined effect of the investigated stressors.

Received 25 April 2013

Accepted 27 June 2013

\section{References}

1. Larcher W. Physiological plant ecology. 4th ed., 2003. Springer. Berlin.

2. Alexieva V, Ivanov S, Sergiev I, Karanov E. Interaction between stresses. Bulg J Plant Physiol 2003; Special Issue, 1-17.

3. Interdonato R, Rosa M, Nieva CB, Gonzlez JA, Hilal M, Prado FE. Effects of low UV-B doses on the accumulation of UV-B absorbing compounds and total phenolics and carbohydrate metabolism in the peel of harvested lemons. Environ Exper Bot 2011; 70: 204-11.

4. Hideg E, Jansen MAK, Strid A. UV-B exposure, ROS, and stress: inseparable companions or loosely linked associates? Trends Plant Sci February 2013; 18(2): 107-15.

5. Booij IS, Dube SK, Jansen MAK, Edelman M, Mattoo AK. Ultraviolet-B radiation impacts light-mediated turnover of the photosystem II reaction center heterodimer in Arabidopsis mutants altered in phenolic metabolism. Plant Physiol 2000; 124: 1275-83.

6. Riquelme A, Wellmann E, Pinto M. Effects of ultraviolet-B radiation on common bean (Phaseolus vulgaris L.) plants grown under nitrogen deficiency. Environ Exper Bot 2007; 60(3): 360-7.

7. Liu LX, Xu SM, Woo KC. Solar UV-B radiation on growth, photosynthesis and the xanthophyll cycle in tropical acacias and eucalyptus 2005; 54: 121-30.

8. Mackerness SAH, Surplus SL, Blake P, John C, Buchanan-Wollaston V, Jordan BR, Thomas B. Ultraviolet-B-induced stress and changes in gene expression in Arabidopsis thaliana: role of signalling pathways controlled by jasmonic acid, ethylene and reactive oxygene species. Plant Cell Environ 1999; 22: 1413-23.

9. Tegelberg R, Julkunen-Tiitto R, Aphalo PJ. The effects of long-term elevated UV-B on the growth and phenolics of field-grown silver birch (Betula pendula). Global Change Biol 2001; 7: 839-48. 
10. Ambasht NK, Agrawal M. Influence of supplemental UV-B radiation on photosynthetic characteristics on rice plants. Photosynthetica 1997; 34: 40-408.

11. Pal M, Sengupta UK, Srivastava AC, Jain V, Meena RC. Changes in growth and photosynthesis of mungbean induced by UV-B radiation. Ind J Plant Physiol 1999; 4: 79-84.

12. Qaderi MM, Reid DM, Yeung EC. Morphological and physiological responses of canola (Brassica napus) siliquas and seeds to $\mathrm{UVB}$ and $\mathrm{CO}_{2}$ under controlled environment conditions. Environ Exper Bot 2007; 60: 42837.

13. Tarkalson DD, Payero JO, Hergert GW, Cassman KG. Acidification of soil in a dry land winter wheat-sorghum/corn-fallow rotation in the semiarid U.S. Great Plains. Plant and Soil. 2006; 283: 367-79.

14. Rodriguez MB, Godeas A, Lavado RS. Soil acidity changes in bulk soil and maize rhizosphere in response to nitrogen fertilization. Communications in Soil Science and Plant Analysis. 2008; 39: 2597-607.

15. Ma JF. Syndrome of aluminum toxicity and diversity of aluminum resistance in higher plants. Int Rev Cyt 2007; 264: 225-52.

16. Haling RE, Simpson RJ, Delhaize E, Hocking PJ, Richardson AE. Effect of lime on root growth, morphology and the rhizosheath of cereal seedlings growing in an acid soil. Plant Soil. 2010; 327: 199-212.

17. Shan Y, Izuta T, Totsuka T. Phenological disorder, cold death of apical shoots of red pine subjected to combined exposures of simulated acid rain and soil acidification, and implications for forest decline. Water Air Soil Poll 2000; 117: 191-203.

18. Hideg E, Jansen MAK, Strid A. UV-B exposure, ROS, and stress: inseparable companions or loosely linked associates? Trends Plant Sci 2013; 18(2): 107-15.

19. Paoletti E. UV-B and acid rain effects on beech (Fagus sylvatica L.) and holm oak (Quercus ilex L.) leaves. Chemosphere 1998; 36(4-5): $835-40$.
20. Januskaitiene I. Effects of substrate acidity and UV-B radiation on photosynthesis of radishes. Centr Eur J Biol 2011; 6(4) 624-31.

21. Growth stages of mono- and dicotyledonous plants. U. Meier (ed.) BBCH monograph. German Federal Biological Research Center for Agriculture and Forests; 2001.

22. Wettstein. Chlorophyll Letale und der submikroskopishe Formweschsel der Plastiden, Exper Cell Res 1957; 12: 427-32.

23. Dai Q, Upadhyaya MK. Seed germination and seedling growth responses of selected weedy species to ultraviolet-B radiation. Weed Sci 2002; 50: 611-5.

24. Day TA, Neale PJ. Effects of UV-B radiation on terrestrial and aquatic primary producers. Ann Rev Ecol Syst 2002; 33: 371-96.

25. Rousseaux MC, Ballare CL, Giordano CV, Scopel AL, Zima AM, Szwarcberg-Bracchitta M, Searles PS, Caldwell MM, Diaz SB. Ozone depletion and UV-B radiation: impact on plant DNA damage in South America. Proc Natl Acad Sci USA 1999; 96: 15310-5.

26. Qaderi MM, Reid DM. Growth and physiological responses of canola (Brassica napus) to UV-B and $\mathrm{CO}_{2}$ under controlled environment conditions. Physiol Plant 2005; 125: 247-59.

27. Izuta $T$, Yamaoka $T$, Nakaji $T$, Yonekura $T$, Yokoyama M, Funada R, Koike T, Totsuka T. Growth, net photosynthesis and leaf nutrient status of Fagus crenata seedlings grown in brown forest soil acidified with $\mathrm{H}_{2} \mathrm{SO}_{4}$ or $\mathrm{HNO}_{3}$ solution. Trees 2004; 18: 677-85.

28. Sharkey TD, Bernacchi CJ, Farquhar GD, Singsaas EL. Fitting photosynthetic carbon dioxide response curves for C3 leaves. Plant Cell Environ 2007; 30: 1035-40.

29. Poulson ME, Boeger MRT, Donahue RA. Response of photosynthesis to high light and drought for Arabidopsis thaliana grown under a UV-B enhanced light regime. Photosyn Res 2006; 90: 79-90.

30. Lidon FC, Ramalho JC. Impact of UV-B irradiation on photosynthetic performance 
and chloroplast membrane components in Oryza sativa L. J Photochem Photobiol B: Biol 2011; 104: 457-66.

31. Cechin I, Fumis TF, Dokkedal AL. Growth and physiological responses of sunflower plants exposed to ultraviolet-B radiation. Ciênc Rur 2007; 37: 85-90.

32. Manetas Y. The importance of being hairy: the adverse effects of hair removal on stem photosynthesis of Verbascum speciosum are due to solar UV-B radiation. New Phytol 2003; 158: 503-8.

33. Sangtarash MH, Qaderi MM, Chinnappa CC, Reid DM. Differential sensitivity of canola (Brassica napus) seedlings to ultraviolet-B radiation, water stress and abscisic acid. Environ Exper Bot 2009; 66: 212-9.

34. Shan Y, Izuta T, Totsuka T. Phenological disorder, cold death of apical shoots of red pine subjected to combined exposures of simulated acid rain and soil acidification, and implications for forest decline. Water Air Soil Poll 2000; 117: 191-203.

35. Shan Y, Izuta T, Aoki M, Totsuka T. Effects of $\mathrm{O}_{3}$ and soil acidification, alone and in combination, on growth, gas exchange rate and chlorophyll content of red pine seedlings. Water Air Soil Poll 1997; 97: 355-66.

36. Ballare CL, Caldwell MM, Robinson SA, Flint SD, Bornman JF. Effects of solar ultraviolet radiation on terrestrial ecosystems. Patterns, mechanisms, and interactions with climate change. Photochem Photobiol Sci 2011; 10: 226-41.

\section{Irena Januškaitienè}

\section{SILPNOS UV-B SPINDULIUOTĖS IR SUBSTRATO RŪGŠTUMO POVEIKIS BRASSICA NAPUS FOTOSINTEZĖS RODIKLIAMS}

\section{Santrauka}

Tyrimo tikslas - ištirti kompleksinį $1 \mathrm{kJm}^{-2} \mathrm{~d}^{-1} \mathrm{UV}-\mathrm{B}$ spinduliuotès ir $\mathrm{pH}$ 4,8 substrato rūgštumo poveiki vasarinių rapsų (Brassica napus) fotosintezės rodikliams bei augimui kontroliuojamoje aplinkoje (fitokamerose). Iš pradžių rapsai buvo pasèti $\mathfrak{i}$ neutralaus rūgštumo $(\mathrm{pH} \quad 6,0-6,5)$ substratą. Augalams išleidus du tikruosius lapelius jie buvo paveikti UV-B spinduliuote, substratas parūgštintas $0,07 \quad \mathrm{mM} \mathrm{H}_{2} \mathrm{SO}_{4}$ koncentracijos tirpalu. Eksperimento trukmé - penkios dienos. Fotosintezès parametrai matuoti nešiojama fotosintezès sistema LI-6400. Pigmentų kiekiai lapuose nustatyti spektrofotometriškai. Didžiausius Brassica napus tirtų rodiklių pokyčius sukèlè kompleksinis $1 \mathrm{kJm}^{-2} \mathrm{~d}^{-1} \mathrm{UV}$-B spinduliuotès ir $\mathrm{pH} 4,8$ substrato rūgštumo poveikis. Pavienis $1 \mathrm{kJm}^{-2} \mathrm{~d}^{-1} \mathrm{UV}-\mathrm{B}$ spinduliuotès poveikis tirtiems rapsų rodikliams buvo silpnas ir statistiškai nereikšmingas, išskyrus transpiracijos intensyvumą bei vandens naudojimo efektyvumą, kai pokyčiai buvo statistiškai reikšmingi. Pavienis substrato rūgštumo poveikis rapsų fotosintezès intensyvumą sumažino 58,6 \% $(\mathrm{p}<0,05)$, transpiracijos intensyvumą - net daugiau nei du kartus ( $\mathrm{p}<0,05)$, o viduląstelinị $\mathrm{CO}_{2}$ kieki $3,8 \%(\mathrm{p}<0,05)$, taip pat $27,1 \%(\mathrm{p}<0,05)$ padidino vandens naudojimo efektyvumą, palyginti su kontroliniais augalais. Patị didžiausią neigiamą poveikį fotosintezès intensyvumui sukèlè UV-B spinduliuotè ir substrato rūgštumas - nuostoliai siekè net $80,6 \%(\mathrm{p}<0,05)$, palyginti su kontroliniais augalais, o kompleksinis tirtų veiksnių poveikis transpiracijos intensyvumui buvo statistiškai nereikšmingas $(\mathrm{p}>0,05)$. Tad nors tik $2 \%$, bet statistiškai reikšmingas $(\mathrm{p}<0,05)$ viduląstelinio $\mathrm{CO}_{2}$ kiekio padidejimas Brassica napus lapuose, esant kompleksiniam tirtų veiksnių poveikiui, rodo stipresni neigiamą poveiki fermentinei fotosintezès sistemai nei transpiracijai. Kompleksinis UV-B ir substrato rugšumo poveikis vèlgi buvo didžiausias ir fotosintetinių pigmentų bei biomasès pokyčiams.

Raktažodžiai: fotosintezès intensyvumas, viduląstelinis $\mathrm{CO}_{2}$ kiekis, transpiracija, vandens naudojimo efektyvumas, fotosintetiniai pigmentai, sausa biomasè, Brassica napus 
